\title{
PENGARUH KONSEP DIRI TERHADAP PRESTASI BELAJAR MATA PELAJARAN PKn SISWA KELAS IV DAN V SD SD NEGERI PANDEYAN YOGYAKARTA TAHUN PELAJARAN 2014/2015
}

\author{
Oleh: \\ Endarti Puriyanti \\ Universitas Cokroaminoto Yogyakarta
}

\begin{abstract}
Abstarak
Psikologi pendidikan dan konsep diri dalam dunia pendidikan sangatlah penting baik dalam pembelajaran maupun bagi pendidik yang harus bisa memahami perilaku dirinya maupun perilaku peserta didik. Begitu pentingnya konsep diri dalam pendidikan akan berpengaruh terhadap perilaku dan prestasi belajar. Siswa dengan konsep diri positif akan memiliki prestasi belajar yang baik. Untuk meningkatkan prestasi belajar siswa sebagai pendidik harus melakukan strategi pembelajaran yang dapat mengembangkan konsep diri siswa.

Subyek penelitian ini adalah konsep diri dan prestasi belajar siswa SD N Pandeyan dengan jumlah sampel sebanyak 47 siswa dalam waktu penelitian antara bulan Mei- Juni. Penelitian ini dilakukan dengan tujuan untuk mengetahui besarnya pengaruh konsep diri terhadap prestasi belajar. Berdasarkan analisis yang dilakukan dengan metode kuesioner untuk mendapatkan data tentang konsep diri dan dokumentasi untuk data prestasi belajar. Dengan analisis statistik deskriptif untuk mengetahui konsep diri dan prestasi belajar siswa . Untuk mengetahui besarnya pengaruh konsep diri terhadap prestasi belajar siswa pada mata pelajaran PKn dilakukan dengan ujiregresi sederhana karena hanya ada satu variabel independen dan satu variabel dependen. Hasil pengujian regresi tunggal adalah koefisien regresi 0,942 dan $R^{2}=0,698$ dengan arti bahwa konsep diri berpengaruh terhadap prestasi belajar sebanyak 69,8\% sedangakan 30,2\% dipengaruhi faktor dari luar penelitian.
\end{abstract}

Kata Kunci : Kecerdasan afektif, konsep diri, perilaku dan prestasi belajar

\section{A. Pendahuluan}

Pendidikan merupakan aspek yang sangat mendasar bagi pembangunan bangsa suatu negara, dalam penyelengaraan pendidikan di sekolah yang melibatkan guru sebagai pendidik dan siswa sebagai peserta didik yang diwujudkan dengan interaksi belajar mengajar atau proses pembelajaran. Dalam konteks penyelenggaraan pembelajaran, guru sebagai pendidik dengan sadar merencanakan pengajarannya secara sistematis dan berpedoman pada seperangkat aturan dan tujuan pendidikan.Sebagaimana dalam Undang-Undang Nomor 20 Tahun 2003 tentang Sistem Pendidikan Nasional pasal 2 bahwa Pendidikan adalah usaha sadar dan terencana untuk 
mewujudkan, mengembangkan potensi dirinya untuk memiliki kekuatan spiritual keagamaan, pengendalian diri, kepribadian, kecerdasan, akhlak mulia serta keterampilan yang diperlukan dirinya. Adapun eksistensi peserta didik dalam masyarakat, membudaya dalam tata kehidupan yang berdimensi lokal, nasional, dan global.

Pendidikan tidak bisa dilepaskan dari psikologi, kontribusi psikologi pendidikan terhadap proses pendidikan sangatlah besar. Tanpa pengetahuan dan pemahaman tentang psikologi dalam proses pendidikan, mustahil proses pengajaran dan pembelajaran akan berjalan lancar. Kegiatan pendidikan, khususnya pada pendidikan folmal seperti pengembangan kurikulum, perilaku individu, proses pembelajaran ,strategi dan metode pembelajaran dan layanan bimbingan konseling merupakan beberapa kegiatan utama dalam pendidikan yang didalamnya tidak bisa dilepaskan dari bidang psikologi. Begitu penting psikologi dalam dunia pendidikan khususnya bagi pendidik, pendidik dituntut untuk bisa memahami dan menguasai berbagai aspek perilaku dirinya maupun perilaku orang lain yang terkait dalam tugasnya, dalam hal ini peserta didik. Disinilah letak arti pentingnya psikologi pendidikan bagi pendidik. Penguasaan pendidik tentang psikologi merupakan salah satu kompetensi yang harus dikuasai guru sebagai pendidik yakni kompetensi pedagogik. Diantaranya pengetahuan yang harus dikuasai guru dan calon guru adalah pengetahuan psikologi terapan yang erat kaitannya dengan proses belajar mengajar peserta didik (Muhibbin Syah, 2005). Pemahaman guru terhadap psikologi siswa sangatlah penting, Siswa dengan berbagai macam latar belakang ekonomi, lingkungan, dan juga keturunan akan mempunyai karakter yang berbeda. Begitu juga dalam hal pemahaman siswa terhadap dirinya sendiri atau konsep diri, walaupun dalam usia yang sama.

Gabriel Marcel (1955), mempertajam konsep diri manusia melalui bukunya Problematic Man (1955) dengan menegaskan bahwa kata kunci untuk memahami konsep diri manusia tidak dapat mengabaikan relasi antar manusia. Bahkan manusia itu ada-dengan-partisipasi (being-byparticipation), yaitu manusia masuk kedalam "ada individunya dengan persekutuannya dengan manusia-manusia lainnya melalui cinta, harapan, dan kepercayaan (Inge Hutagalung, 2007:23). Pemahaman konsep diri sangat penting begitu juga kecerdasan afektif yang merupakan objek yang sangat dominan diperhatikan dalam pendidikan. Realita pendidikan di Indonesia hanya menekankan dari segi kognotif saja dalam hal ini prestasi akademik, guru kurang memahami psikologi siswa padahal pendidikan menyangkut berbagai aspek kemanusiaan seperti 
pengetahuan, sosial, moral, religius dan juga hati. Secara kognitif pandai tetapi hati,emosi, dan kepribadiannya tidak tertata bahkan berperilaku menyimpang. Hal tersebut dipertegas menurut Iskandar Doktor Psikologi Pendidikan dari Kebangsaan Malaysia menyatakan bahwa pembelajaran dilembaga pendidikan sekolah dan di perguruan tinggi kita selama ini cenderung menggunakan kemampuan matematis-logis dan bahasa, (kecerdasan intelektual) akibatnya membunuh kemampuan lainnya (Iskandar, 2012:69).

Mata pelajaran keterampilan emosi ini berakar jauh pada gerakan pendidikan afektif pada tahun 1960-an. Pemikiran yang ada pada waktu itu adalah bahwa pelajaran psikologi dan yang bersifat memotivasi akan dapat dipelajari lebih mendalam andai kata pelajaran itu secara konseptual melibatkan pengalaman langsung tentang apa yang sedang diajarkan. Tetapi, gerakan keterampilan emosional mengubah istilah pendidikan afektif secara terbalik bukan menggunakan perasaan untuk mendidik, melainkan mendidik perasaan itu sendiri (Daniel Goleman, 2015:370). Pendidikan di Indonesia, dengan ditambahkannya mata pelajaran pendidikan karakter diharapkan akan mencetak lulusan yang perbudi pekerti baik, berakhlak agamis, serta berperilaku baik.Karena tingkat keberhasilan siswa tidak hanya ditentukan dari kemampuan intelektual saja tetapi dari segi afektif terutama konsep diri. Untuk membentuk konsep diri yang baik, terlebih dahulu harus mengenali diri sendri karena diri (self) merupakan kunci utama dalam kerangka kehidupan (James, 2002). Untuk itu konsep diri dapat dianalogikan sebagai sistem operasi yang menjalankan komputer mental, yang mempengaruhi kemampuan berpikir dan mempunyai pengaruh besar terhadap level kesadaran seseorang.

Konsep diri individu berbeda dan berubah, semakin baik atau positif konsep diri seseorang maka akan semakin mudah mencapai keberhasilan. Sebab dengan konsep diri yang baik atau positif seseorang akan optimis, berani mencoba hal-hal baru, berani sukses dan berani gagal pula, penuh percaya diri, antusias, merasa diri berharga, berani menetapkan tujuan hidup serta bersikap positif dan berpikir secara positif. Sebaliknya semakin jelek atau negatif konsep diri, maka akan semakin sulit seseorang untuk berhasil. Karena dengan konsep diri yang jelek atau negatif akan mengakibatkan tumbuh rasa tidak percaya diri, takut gagal sehingga tidak berani untuk mencoba hal-hal yang baru, malu dalam bergaul, merasa bodoh, dan rendah diri.Fink (Burns, 1982) melakukan penelitian dengan melibatkan sejumlah siswa laki-laki dan perempuan yang dipasangkan berdasarkan tingkat intelegensi mereka, yaitu kelompok 
berprestasi lebih (overachiever) dan kelompok yang berprestasi kurang (underchiever). Hasil penelitian ini menunjukkan bahwa terdapat perbedaan konsep diri antara siswa yang tergolong overachiever dan underachiever. Siswa yang tergolong overachiever menunjukkan konsep diri yang lebih positif, dan pengaruh positif antara konsep diri dengan prestasi belajar terlihat jelas pada siswa laki-laki (Desminta, 2010: 171)

Konsep diri merupakan komponen yang sangat vital dalam kehidupan khususnya dalam dunia pendidikan. Karena merupakan salah satu aspek perkembangan psikologi peserta didik yang penting dipahami pendidik. Hal ini disebabkan, konsep diri merupakan variabel yang menentukan dalam proses pendidikan dalam hal ini pembelajaran, banyak bukti yang menguatkan bahwa rendahnya motivasi belajar dan prestasi siswa serta terjadi penyimpanganpenyimpangan perilaku siswa dikelas yang banyak disebabkan oleh persepsi dan sikap negatif terhadap dirinya sendiri, sebaliknya siswa yang memiliki konsep diri positif akan berprestasi dalam belajar. Seolah-olah konsep diri merupakan penentu siswa dalam belajar, penentu siswa dalam berprestasi, tetapi hal ini tidak dapat dipungkiri bahwa konsep diri berpengaruh terhadap prestasi belajar. Oleh karena itu dalam rangka meningkatkan kualitas pendidikan di sekolah guru perlu melakukan upaya-upaya yang memungkinkan terjadinya peningkatan konsep diri siswa.

\section{B. Metode}

Teknik pengumpulan data menggunakan kuesioner dan dokumnetasi.Pengukuran kuesioner mengunakan semantic deferential.Semantic deferential digunakan untuk mengukur sikap, tetapi bentuknya tidak pilihan ganda maupun checklist, tetapi tersusun dalam satu garis kontinum yang jawabannya sangat positif terletak dibagian kanan garis, dan jawabannya yang sangat negatif terletak dibagian kiri garis, atau sebaliknya. Data yang diperoleh untuk mengukur sikap atau karakteristik tertentu yang dipunyai oleh seseorang (Sugiyono, 2002:91).

Metode dokumentasi yaitu mencari data-data mengenai hal-hal atau variabel berupa catatan, transkrip, buku, surat kabar, majalah, prasasti, notulen rapat, legger, agenda, sebagainya (Suharsimi Arikunto, 2002:206). Dokumentasi untuk mengambil nilai rapor mata pelajaran PKn semester genaptahun 2015 . 
Kriteria prestasi belajar untuk mengukur nilai rapor ditunjukkan dalam tabel 1:

Tabel 1

Kriteria prestasi belajar

\begin{tabular}{|l|l|l|}
\hline No & \multicolumn{1}{|c|}{ Skor } & \multicolumn{1}{c|}{ Kriteria } \\
\hline 1 & $\leq 12$ & Gagal \\
\hline 2 & $13-25$ & Kurang \\
\hline 3 & $26-38$ & Cukup \\
\hline 4 & $39-51$ & Baik \\
\hline 5 & 252 & Baik Sekali \\
\hline
\end{tabular}

Sumber : Data diolah

Berdasarkan tabel 1 dapat disimpulkan bahwa kriteria belajar terdiri dari 5 interval dengan kriteria gagal dengan skor $\leq 12$, kurang dengan skor 13-25, cukup dengan skor 26-38, baik dengan skor 39-51 dan baik sekali dengan skor $\geq 52$.

\section{Pembahasan}

1. Uji Validitas

Uji validitas dalam penelitian ini menggunakan progam SPSS Versi 22 (Statistical Product and Service Solutions).Adapun rumusnya adalah sebagai berikut (Suharsimi Arikunto, 2010:274):

$$
\boldsymbol{r}_{x y}=\frac{N \sum X Y-\left(\sum X\right)\left(\sum Y\right)}{\sqrt{\left\{N \sum X^{2}-\left(\sum X^{2}\right)\right\}\left\{N \sum Y^{2}-\left(\sum Y^{2}\right)\right\}}}
$$

Keterangan :

r : Koefisien korelasi

$\mathrm{N}$ : Banyaknya sampel

$\mathrm{X}:$ Skor X

Y : Skor Y

Untuk mengetahui sejauh mana ketepatan dan kecermatan instrumen dalam melakukan fungsi ukurnya, ini merupakan tujuan uji validitas. Instrumen yang valid berarti alat ukur yang digunakan untuk mengukur tersebuttepat. Biasanya syarat minimum untuk dianggap memenuhi 
syarat adalah kalau $r=0,3$. Jadi kalau korelasi antara butir dengan skor total kurang dari 0,3 maka butir dalam instrumen tersebut dinyatakan tidak valid (Sugiyono, 2002:124). Suatu instrumen dikatakan valid apabila koefisien korelasinya (r) 0,3 .

a) Uji validitas instrumen dengan indikator pengetahuan

Hasil uji validitas instrumen dengan indikator pengetahuan ditunjukkan dalam tabel 2.

Tabel 2

Uji validitas instrumen dengan indikator pengetahuan

\begin{tabular}{|c|c|c|c|}
\hline Instrumen & Pearson Corelation & Koefisien Korelasi & Keterangan \\
\hline \multicolumn{4}{|c|}{$\begin{array}{c}\text { Dimensi Pengetahuan } \\
\end{array}$} \\
\hline P1 & 0,488 & 0,3 & Valid \\
\hline P2 & 0,323 & 0,3 & Valid \\
\hline P3 & 0,150 & 0,3 & Tidak Valid \\
\hline P4 & 0,313 & 0,3 & Valid \\
\hline W1 & 0,214 & 0,3 & Tidak Valid \\
\hline W2 & 0,550 & 0,3 & Valid \\
\hline W3 & 0,155 & 0,3 & Tidak Valid \\
\hline W4 & 0,434 & 0,3 & Valid \\
\hline S1 & 0,517 & 0,3 & Valid \\
\hline S2 & 0,464 & 0,3 & Valid \\
\hline S3 & 0,615 & 0,3 & Valid \\
\hline S4 & 0,352 & 0,3 & Valid \\
\hline S5 & 0,571 & 0,3 & Valid \\
\hline S6 & 0,352 & 0,3 & Valid \\
\hline
\end{tabular}

Sumber : Data diolah

Keterangan :

P1 : Sebagai siswa SD N Pandeyan Yogyakarta yang rajin belajar

P2 : Sebagai anggota perpustakaan SD N Pandeyan Yogyakartaa

P3 : Sebagai anggota pramuka di SD N Pandeyan Yogyakarta yang aktif

P4 : Sebagai anak yang menyayangi keluarga

W1 : Mengucapkan terimakasih setelah menerima bantuan dari teman

W2 : Berdoa sebelum belajar

W3 : Meminta maaf atas kesalahan yang saya lakukan

W4 : Menghormati teman yang berbeda agama

S1 : Tegas dalam mengambil keputusan

S2 : Melakukan kegiatan tanpa ragu-ragu

S3 : Mengembalikan barang tepat waktu 
S4 : Rendah diri kepada semua orang termasuk teman

S5 : Ikhlas membantu teman yang sedang membutuhkan bantuan

S6 : Ramah kepada guru dimana saja

Berdasarkan hasil perhitungan pearson correlationpada tabel 2 dapat disimpulkan bahwa, terdapat instrumenyang tidak valid sebanyak 3yaitu P3, W1 dan W3.

b) Uji validitas instrumen dengan indikator harapan atau cita-cita

Hasil uji validitas instrumen dengan indikator harapan atau cita-cita ditunjukkan dalam tabel 3.

Tabel 3

Uji validitas dimensi cita-cita

\begin{tabular}{|c|c|c|c|}
\hline Instrumen & Pearson Correlation & Koefisien Korelasi & Keterangan \\
\hline \multicolumn{4}{|c|}{ Dimensi Cita-cita } \\
\hline ABO1 & 0,430 & 0,3 & Valid \\
\hline $\mathrm{ABO} 2$ & 0,531 & 0,3 & Valid \\
\hline $\mathrm{ABO} 3$ & 0,329 & 0,3 & Valid \\
\hline $\mathrm{ABO} 4$ & 0,490 & 0,3 & Valid \\
\hline $\mathrm{ABO5}$ & 0,503 & 0,3 & Valid \\
\hline ABL1 & 0,436 & 0,3 & Valid \\
\hline ABL2 & 0,206 & 0,3 & Tidak Valid \\
\hline ABL3 & 0,457 & 0,3 & Valid \\
\hline ABL4 & 0,307 & 0,3 & Valid \\
\hline GB1 & 0,577 & 0,3 & Valid \\
\hline GB2 & 0,503 & 0,3 & Valid \\
\hline GB3 & 0,319 & 0,3 & Valid \\
\hline GB4 & 0,534 & 0,3 & Valid \\
\hline GB5 & 0,226 & 0,3 & Tidak Valid \\
\hline
\end{tabular}

Sumber : Data diolah

Keterangan:

ABO1 : Membantu kedua orang tua membersihkan rumah

ABO2 : Patuh kepada kedua orang tua

ABO3 : Tidak mengecawakan kedua orag tua

ABO4 : Mendoakan kedua orang tua setelah beribadah

ABO5 : Melaksanakan apapun yang diperintakan kedua orang tua

ABL1 : Meminjamkan buku kepada teman kerena belum mempunyai buku

ABL2 : Memberi semangat teman yang putus asa

ABL3 : Menolong teman yang mengalami musibah 
GB1 : Menjadi guru yang tidak membeda-bedakan siswa

GB2 : Menjadi guru yang tidak memberi tugas terlalu banyak

GB3 : Menjadi guru membimbing siswa yang mengalami kesulitan dalam belajar

GB4 : Menjadi guru yang memberi semangat kepada siswa agar tetap rajin belajar

GB5 : Menjadi guru yang datang ke sekolah sebelum bel masuk

Berdasarkan hasil perhitungan pearson correlationpada tabel 3 dapat disimpulkan bahwa, terdapat instrumen yang tidak valid sebanyak2 yaitu ABL2 dan GB5.

c) Uji validitas instrumen dengan indikator penilaian

Hasil uji validitas instrumen dengan indikator penilaian ditunjukkan dalam tabel 4.

Tabel 4

Uji validitas dimensi penilaian

\begin{tabular}{|c|c|c|c|}
\hline Instrumen & Pearson Correlation & Koefisien Korelasi & Keterangan \\
\hline \multicolumn{4}{|c|}{ Dimensi Penilaian } \\
\hline KCPB1 & 0,717 & 0,3 & Valid \\
\hline KCPB2 & 0,465 & 0,3 & Valid \\
\hline KCPB3 & 0,558 & 0,3 & Valid \\
\hline KPDS1 & 0,471 & 0,3 & Valid \\
\hline KPDS2 & 0,469 & 0,3 & Valid \\
\hline KPDS3 & 0,727 & 0,3 & Valid \\
\hline KPDS4 & 0,479 & 0,3 & Valid \\
\hline KPDS5 & 0,621 & 0,3 & Valid \\
\hline KPDS6 & 0,542 & 0,3 & Valid \\
\hline KPDS7 & 0,371 & 0,3 & Valid \\
\hline KDB1 & 0,487 & 0,3 & Valid \\
\hline KDB2 & 0,319 & 0,3 & Valid \\
\hline KDB3 & 0,335 & 0,3 & Valid \\
\hline KDB4 & 0,650 & 0,3 & Valid \\
\hline KDB5 & 0,092 & 0,3 & Tidak Valid \\
\hline
\end{tabular}

Sumber : Data diolah

Keterangan :

KCPB1 : Mendapatkan nilai sedang tetapi tidak mencontek

KCPB2 : Bersikap jujur walaupun tidak bisa mengerjakan soal

KCPB3 : Tidak bisa bekerjasama dalam kelompok tetapi tidak menang sendiri

KPDS1 : Menghormati teman yang berbicara didepan kelas karena tidakberani berbicara didepan kelas 
KPDS2 : Tidak berani bertanya tetapi menghormati teman yang sedang bertanya

KPDS3 : Tidak bisa menjawab pertanyaan tetapi menghormati teman yang menjawab pertanyaan

KPDS4 : Tidak mampu membuat keputusan tetapi menerima keputusan teman

KPDS5 : Tetap semangat walaupun mengalami kegagalan

KPDS6 : Percaya diri dalam bergaul tetapi suka meremehkan teman

KPDS7 : Ragu-ragu dalam melakukan kegiatan tetapi tidak sombong

KDB1 : Meminta ijin kepada guru untuk masuk kelas karena terlambat

KDB2 : Mengerjakan tugas sendiri walaupun terlambat mengumpulkannya

KDB3 : Mengerjakan tugas dengan baik walaupun dengan bantuan orang lain

KDB4 : Tidak membawa buku pelajaran tetapi tetap mengikuti pembelajaran dengan satu buku berdua dengan teman

KDB5 : Tidak memakai seragam sekolah tetapi menjelaskan kepada guru penyebabnya

Berdasarkan hasil perhitungan pearson correlationpada tabel 4 terdapat instrumen yang tidak valid yaitu KDB5. Sehingga dapat disimpulkan bahwa instrumen pada dimensi pengetahuan yaitu P3, W1 dan W3, dimensi cita-cita yaitu ABL2 dan GB5 dan dimensi penilaian yaitu KDB5 tidak valid maka tidak digunakan untuk analisis selanjutnya sedangkan instrumen yang tersisa mempunyai koefisien $(r)>0,3$ yang artinya seluruh instrumenpada variabel penelitian dinyatakan valid, sehingga instrumen tersebut dapat dinyatakan layak sebagai instrumen untuk mengukur data penelitian.

\section{Uji Reliabilitas}

Uji reliabilitas dilakukan untuk menguji apakah instrumen yang sudah diisi responden reliabel. Instrumen yang reliabel adalah instrumen yang bila digunakan beberapa kali untuk mengukur objek yang sama dan dalam waktu yang berbeda akan menghasilkan nilai yang sama. Hal ini ditunjukkan dengan keajegan skor atau hasil.Suatu instrumen data dikatakan reliabel apabila nilai Alpha Cronbach >0,6 (Sugiyono, 2005: 183). Uji reliabilitas dilakukan dengan rumus Alpha Cronbach sebagai berikut:

$$
\boldsymbol{T}_{11}=\left(\frac{\mathrm{k}}{\mathrm{k}-1}\right)\left(1-\frac{\sum \sigma_{b}^{2}}{\sigma_{1}^{2}}\right)
$$

Keterangan : 
$r_{11}:$ Reliabilitas instrumen

$\mathrm{K}$ : Banyaknya butir pernyataan atau banyaknya soal

$\sum \sigma_{b}^{2}:$ Jumlah varian butir

$\sigma_{1}^{2}:$ Varian total

Hasil uji reliabilitasinstrumen dengan indikator pengetahuan, harapan atau cita-cita dan penilain ditunjukkan dalam tabel 5.

Tabel 5

Uji reliabilitas instumen dengan indikator pengetahuan, indikator harapan atau cita-cita dan indikator penilaian

\begin{tabular}{|l|l|l|}
\hline Instrumen & Cronbach Alpha & Keterangan \\
\hline Dimensi pengetahuan & 0,62 & Reliabel \\
\hline Dimensi Cita-cita & 0,583 & Tidak reliabel \\
\hline Dimensi penilaian & 0,798 & Reliabel \\
\hline
\end{tabular}

Sumber : Data diolah

Berdasarkan hasil uji reliabilitas terdapat instrumen yang tidak reliabel karenacoeficient cronbach alpha< 0,6 yaitu instrumen pada dimensi cita-cita sedangkan instrumen pada dimensi pengetahuan dan dimensi penilaian reliabel.

\section{Teknik Analisis Data dan Pengujian Hipotesis}

1. Analisis Statistik Deskriptif

Analisis data dalam penelitian ini menggunakan statsitik deskriptif. Statistik deskriptif adalah statistik yang digunakan untuk menganalisis data dengan cara mendeskripsikan atau menggambarkan data yang telah terkumpul sebagaimana adanya tanpa bermaksud membuat kesimpulan yang berlaku untuk umum atau generalisasi (Sugiyono, 2002: 142). Analisis data dalam penelitian ini menggunakan rumus persentase:

$$
\mathrm{P}=\frac{\mathrm{F}}{\mathrm{N}} \mathrm{x} 100 \%
$$

Keterangan:

P : Persentase

F : Frekuensi jawaban responden

$\mathrm{N}$ : Jumlah responden 
Analisis statistik deskriptif siswa antara lain dari segi jenis kelamin, usia, dan nilai rapor mata pelajaran PKn semester genap dan juga analisis jawaban siswa.Untuk lebih jelasnya akan diuraikan sebagai berikut.

a) Jenis Kelamin

Karakteristik siswa dari segi jenis kelamin ditunjukkan dalam tabel 6.

Tabel 6

Karakteristik siswa berdasarkan jenis kelamin

\begin{tabular}{|ll|l|l|l|}
\hline & & Frequency & Percent & Valid Percent \\
\hline Valid & Laki-laki & 24 & 51,1 & 51,1 \\
& Perempuan & 23 & 48,9 & 48,9 \\
& Total & 47 & 100,0 & 100,0 \\
\hline
\end{tabular}

Sumber : Data diolah

Berdasarkan tabel 6 dapat disimpulkan bahwa jumlah jenis kelamin siswa hampir sama yaitu responden jenis kelamin laki-laki berjumlah 24 atau 51,1\% sedangkan siswa jenis kelamin perempuan berjumlah 23 atau 48,9\%.

b) Usia

Karakteristik siswa berdasarkan usia ditunjukkan dalam tabel 7.

Tabel 7

Karakteristik siswa berdasarkan usia

\begin{tabular}{|ll|c|c|c|}
\hline & & Frequency & Percent & Valid Percent \\
\hline Valid & 9 tahun & 1 & 2,1 & 2,1 \\
& 10 tahun & 17 & 36,2 & 36,2 \\
& 11 tahun & 18 & 38,3 & 38,3 \\
& 12 tahun & 10 & 21,3 & 21,3 \\
& 13 tahun & 1 & 2,1 & 2,1 \\
& Total & 47 & 100,0 & 100,0 \\
\hline
\end{tabular}

Sumber : Data diolah

Berdasarkan tabel 7 dapat disimpulkan sebagian kecil usia siswa 9 dan 13 tahun masing-masing sebanyak 1 siswa atau 2.1\%. siswa dengan usia 10 dan 11 tahun hanya selisih 1 angka masing-masing sebanyak 17 dan 18 siswa atau 36,2\% dan 38,3\% sedangkansiswa berusia 12 tahunsebanyak 10 siswa atau $21,3 \%$.

c) Nilai Rapor

Karakteristik siswa dari segi nilai rapor dapat dilihat dalam tabel 9. 
Tabel 9

Nilai rapor siswa berdasarkan kriteria prestasi belajar

\begin{tabular}{|c|c|c|c|}
\hline No & Skor & Jumlah siswa & Kriteria \\
\hline 1 & $\leq 2$ & 0 & Gagal \\
\hline 2 & $13-25$ & 0 & Kurang \\
\hline 3 & $26-38$ & 0 & Cukup \\
\hline 4 & $39-51$ & 0 & Baik \\
\hline 5 & $\geq 52$ & 47 & Baik Sekali \\
\hline
\end{tabular}

Sumber : Data diolah

Berdasarkan tabel 9 dapat disimpulkan bahwa, semua nilai rapor siswa dengan skor 252 atau 47 atau $100 \%$ dengan kriteria baik sekali.

d) Jawaban Siswa

Hasil analisis dari indikator pengetahuan dengan instrumen, sebagai anak yang menyayangi keluarga ditunjukkan dalam tabel 10.

Tabel 10

Instrumen peran sebagai anak yang menyayangi keluarga

\begin{tabular}{|c|c|c|c|c|}
\hline & & Frequency & Percent & Valid Percent \\
\hline \multirow[t]{4}{*}{ Valid } & $\begin{array}{l}\text { Sangat tidak } \\
\text { setuju } \\
\text { Tidak setuju }\end{array}$ & $\begin{array}{l}0 \\
0\end{array}$ & $\begin{array}{l}0,00 \\
0,00\end{array}$ & $\begin{array}{l}0,00 \\
0,00\end{array}$ \\
\hline & Setuju & 6 & 12,8 & 12,8 \\
\hline & Sangat setuju & 41 & 87,2 & 87,2 \\
\hline & Total & 47 & 100.0 & 100.0 \\
\hline
\end{tabular}

Sumber : Data diolah

Berdasarkan tabel 10 dapat disimpulakan bahwa, mayoritas siswa sangat setuju menjadi anak yang menyayangi keluarga sebanyak 41 atau $87,2 \%$.

2. Pengujian Hipotesis

Pengujian hipotesis dilakukan untuk mengetahui besarnya pengaruh variabel independen terhadap variabel dependen. Dengan cara langsung mengkonsultasikan pada tabel $\mathrm{r}$ product moment (r tabel). Dengan taraf kesalahan 5\%, maka akan diperoleh $\mathrm{r}$ tabel dengan ketentuan bahwa bila $r_{h}$ dari $r_{t}$ maka $H_{Q}$ diterima dan $H_{a}$ ditolak. Sebaliknya bila $r_{h}$ dari $r_{t}$ maka $H_{a}$ diterima dan $H_{o}$ ditolak.Analisis korelasi dapat dilanjutkan dengan menghitung koefisien 
determinan, dengan cara mengkuadratkan nilai koefisien. Pengujian hipotesis dilakukan dengan analisis regresi tunggal dengan persamaan sebagai berikut:

$$
\mathrm{Y}=\mathrm{a}+\mathrm{bX}
$$

\section{Keterangan:}

Y : variabel terikat

X : variabel bebas

a : konstanta

b : koefisien regresi

Hasil pengujian regresi tunggal ditunjukkan dalam tabel tabel 11

Tabel 11

\section{Coefficients $^{\mathrm{a}}$}

\begin{tabular}{|ll|l|l|l|l|l|}
\hline \multirow{2}{*}{ Model } & & \multicolumn{2}{|l|}{$\begin{array}{l}\text { Unstandardized } \\
\text { Coefficients }\end{array}$} & $\begin{array}{l}\text { Standardized } \\
\text { Coefficients }\end{array}$ & & \\
\cline { 2 - 6 } & & B & Std. Error & Beta & T & Sig. \\
\hline & (Constant) & 21,756 & 5,441 & & 3,999 &, 000 \\
& Konsep Diri &, 942 &, 092 &, 836 & 10,209 &, 000 \\
\hline
\end{tabular}

a. Dependent Variable: Prestasi Belajar

Sumber : Data diolah

Berdasarkan tabel 9 dapat diperoleh persamaan regresi tunggalY=21,756+0,942X

1. Konstanta $(\alpha)$ sebesar 21,756 dengan pengertian jika konsep diri $(\mathrm{X})$ atau sama dengan nol (0) maka besarnya tingkat prestasi belajar (Y) sebesar 21,756 satuan.

2. Variabel konsep diri (X) diperoleh nilai koefisien sebesar 0,942 yang berarti apabila nilai konsep diri (X) meningkat satu satuan maka prestasi belajar (Y) akan meningkat sebesar 0,942 satuan.

3. Pengujian hipotesis dilakukan melalui pengujian signifikansi koefisien regresi variabel konsep diri. Dengan hipotesis konsep diri berpengaruh terhadap prestasi belajar siswa. Hasil analisis tabel 59 besarnya koefisien regresi 0,942 dengan tingkat signifikansi $\alpha=5 \%$, maka koefisien regresi tersebut signifikan karena $\rho=0,000<0,05$. 
Tabel 12

Analisis regresi tunggal

Model Summary

\begin{tabular}{|c|c|c|c|c|c|c|c|c|c|}
\hline \multirow[b]{2}{*}{ Model } & \multirow[b]{2}{*}{$\mathrm{R}$} & \multirow[b]{2}{*}{$\begin{array}{l}\mathrm{R} \\
\text { Square }\end{array}$} & \multirow[b]{2}{*}{$\begin{array}{l}\text { Adjusted } \\
\text { R Square }\end{array}$} & \multirow{2}{*}{$\begin{array}{l}\text { Std. Error } \\
\text { of the } \\
\text { Estimate }\end{array}$} & \multicolumn{5}{|c|}{ Change Statistics } \\
\hline & & & & & $\begin{array}{l}\mathrm{R} \text { Square } \\
\text { Change }\end{array}$ & $\begin{array}{l}\mathrm{F} \\
\text { Change }\end{array}$ & df1 & df2 & $\begin{array}{l}\text { Sig. F } \\
\text { Change }\end{array}$ \\
\hline 1 &, $836^{\mathrm{a}}$ & ,698 & ,692 & 2,715 & ,698 & 104,217 & 1 & 45 & ,000 \\
\hline
\end{tabular}

a. Predictors: (Constant), Konsep Diri

b. Dependent Variable: Prestasi Belajar

Untuk mengetahui besarnya pengaruh variabel independen terhadap variabel dependen dilakukan dengan pengujian hipotesis dengan analisis regresi tunggal.Berdasarkan model summary dari hasil pengujian hipotesis terdapat nilai koefisien korelasi 0,386.

\section{Kesimpulan}

1. Konsep diri siswa SD N Pandeyan baik hal ini dapat dilihat dari hasil analisis statistik deskriptif instrumen. Dari hasil analisis statistik deskriptif dapat disimpulkan bahwa konsep diri siswa SD N Pandeyan baik

2. Prestasi belajar siswa SD N Pandeyan baik sekali hal ini dapat dilihat dari hasil nilai rapor mata pelajaran PKn semester genap. Nilai rapor siswa mayoritas dengan skor 13-25 sebanyak 43 siswa sehingga dapat disimpulkan bahwa prestasi belajar mata pelajaran PKn siswa kelas IV dan V SD N Pandeyan dengan kriteria cukup

3. Berdaarkan hasil pengujian hipotesis dapat disimpulkan bahwa konsep diri berpengaruh positif terhadap prestasi belajar. Hal ini dapat dilihat dari hasil uji hipotesis bahwa koefisien regresi 0,942. Sehingga dapat disimpulkan bahwa konsep diri berpengaruh positif dan signifikan terhadap prestasi belajar sebanyak 94,2\% sedangkan 5,8\% dipengaruhi faktor dari luar penelitian 


\section{DAFTAR PUSTAKA}

Daniel Goleman, (2015), “Emotional Intellegence”, Jakarta: Gramedia

Desminta, (2010), “Psikologi Perkembangan Peserta Didik”, Bandung: Remaja Rosdakarya

Elizabeth B. Hurlock, (1980), “Psikologi Perkembangan Suatu Pendekatan Sepanjang Rentang Kehidupan", Jakarta:Erlangga

Husein Umar, (2001), “Metode Penelitin Untuk Skripsi dan Tesis”, Jakarta: Rajawali Pres

Inge Hutagalung, (2007), “Pengembangan Kepribadian, Tinjauan Praktis Menuju Pribadi Positif', Jakarta: Indeks

Iskandar, (2012), “Psikologi Pendidikan (Sebuah Orientasi Baru)”, Jakarta: Referensi

Muhibbin Syah, (2004), "Psikologi Pendidikan dengan Pendekatan Baru”, Bandung: Remaja Rosdakarya

Sugiyono, (2002), "Metode Penelitian Bisnis", Bandung: Alfabeta

Suharsimi Arikunto, (2010), "Preosedur Penelitan : Suatu Pendekatan Praktis", Jakarta: Rineka Cipta. 